\title{
Spatial Variability of Vegetation in the Changing Climate of the Baikal Region
}

\author{
A. P. Sizykh and V. I. Voronin \\ Additional information is available at the end of the chapter \\ http://dx.doi.org/10.5772/55481
}

\section{Introduction}

Thesystems of environments contact sites are somewhat models reflecting practically allchanges occurring in any hierarchic systems. Recently different approaches to the assessment of such processes as paragenesis manifestation in the environments are proposed. There are some suppositions on manifestation of polyzonality (binarity) of the environments, especially at the local level of their organization of the background of climate changes. Here, on the author's opinion, the geomorphology peculiarities and edaphic conditions in polyzonality formation at the regional level of the environment organization are manifested. The validity of use of concrete terms characterizing one or other environments is discussed. In particular, conclusions on the opportunity of use the term "zonal habitat" in the characterization of flat interfluve vegetation and soils are very curious. In this context, the use of polysystem modeling method and of ones of systematic mapping analysis of environments organization and dynamics will promote resolution of concrete tasks for indication and forecasting of environments contact systems. The vegetation structure of the Prebaikalia reveals a certain relation to the evolution history of the natural environment of the entire Baikal region. In the tertiary era the territory of the presentdayPrebaikaliawasoccupied bybroad-leaved forestswherevalleysanddrydepressionsbetween mountains were dominated by xerophyte grass communities (Grichuk, 1955; Dylis, Reshchikov, Malyshev, 1965). Tectonic movements and changes of climate were responsible for the disappearance of the heat-loving flora. The landscapes of the Baikal region have attained their modern character during the last 10-12 thousand years. The development of the vegetative cover in the Prebaikalia dates back to the Holocene (Belova, 1975, 1985; Savina, 1986; Bezrukova, 1996, 2002). Climate fluctuations over the course of the Holocene were responsible for the characteristic properties of spatial variability and dynamics of the interrelationship between the various types of vegetation in the region, in the character of changes in the species composition, of the 
predominant kinds of layers, and of change sin the areas occupied by different types of communities (forestand steppe communities) at different periods of the Holocene. The relative increase in the amount of yearly mean summertime precipitation and yearly mean winter temperatures (Gustokashina, 2003) qualitatively alter the conditions of the forming environment, the cause for the tendencies of the region's vegetation (and the natural environment as a whole) to develop. A highly instructive example with regards to identifying the dynamic properties of the communities that develop in the zone of contact of the types of vegetation, and the factors that are responsible for them, is provided by a publication (Thomas T. Veblen, Diana C. Lorenz, 1988) which treats the problem of vegetation changes in the "forest-steppe" ecotone zone in Northern Patagonia.

For spatial variability of vegetation in the changing climate there are quit new information for Ural mountain systems (Shyatov et al., 2005; Kapralov et al., 2006, and others).

Some new information about current structure and tendency of the vegetation formation around Lake Baikal we have get for last years, just for some of territories of the Baikal region.

The aim of our studies is determining of main peculiarities of structural and dynamical communities organization forming under the conditions of mutual development of extra zonal steppes and taiga with identification of nowadays tendencies of communities genesis under the conditions of changing climatic situation and of dynamics of anthropogenic impacts in the region. The areas investigation there are on the map (Fig.1.).

\section{Methods}

This study is based on using the method of large-scale mapping of the vegetation in conjunction with field aerospace photography interpretation of a different scale, by generating maps on a scale 1 : 25000 - 1: 100 000. By laying transect-profiles and using geobotanical descriptions for different years, it was possible to identify areas reflecting the whole spectrum of the typological composition of the region's communities. These model areas are representative throughout the entire spatial structure of vegetation and were the objects of monitoring of the dynamics and genesis of communities that develop in different environmental conditions and reflecting different types of the region's vegetation. A many-year (15 years) monitoring in the model areas using aerospace photographs from different years (1972-2002) for the territory of the Prebaikalia was instrumental in revealing the typological composition of communities, with a certain set of plant species, diagnostic tools for communities of different conditions of development. The selection of a territory where profiling is to be performed requires always natural phenomenon analysis, its concrete characteristics or a particular structure and is always individual. The relief structure, taking into account differences in relative heights, the situation of a territory in a mountain system, if available, as well as driangle system analysis (river basin, lake coast, etc) determine the profile site and length. A geobotanic profile aimed to reveal the spatial variability of communities structure is established taking into account the peculiarities of vegetation on a territory depending on the range - topologic, regional, zonal, etc. One of the methods for revealing structure, spatial variability and interaction of phytocenoses in environments contact sites with edaphic conditions, on our opinion, can be combined 


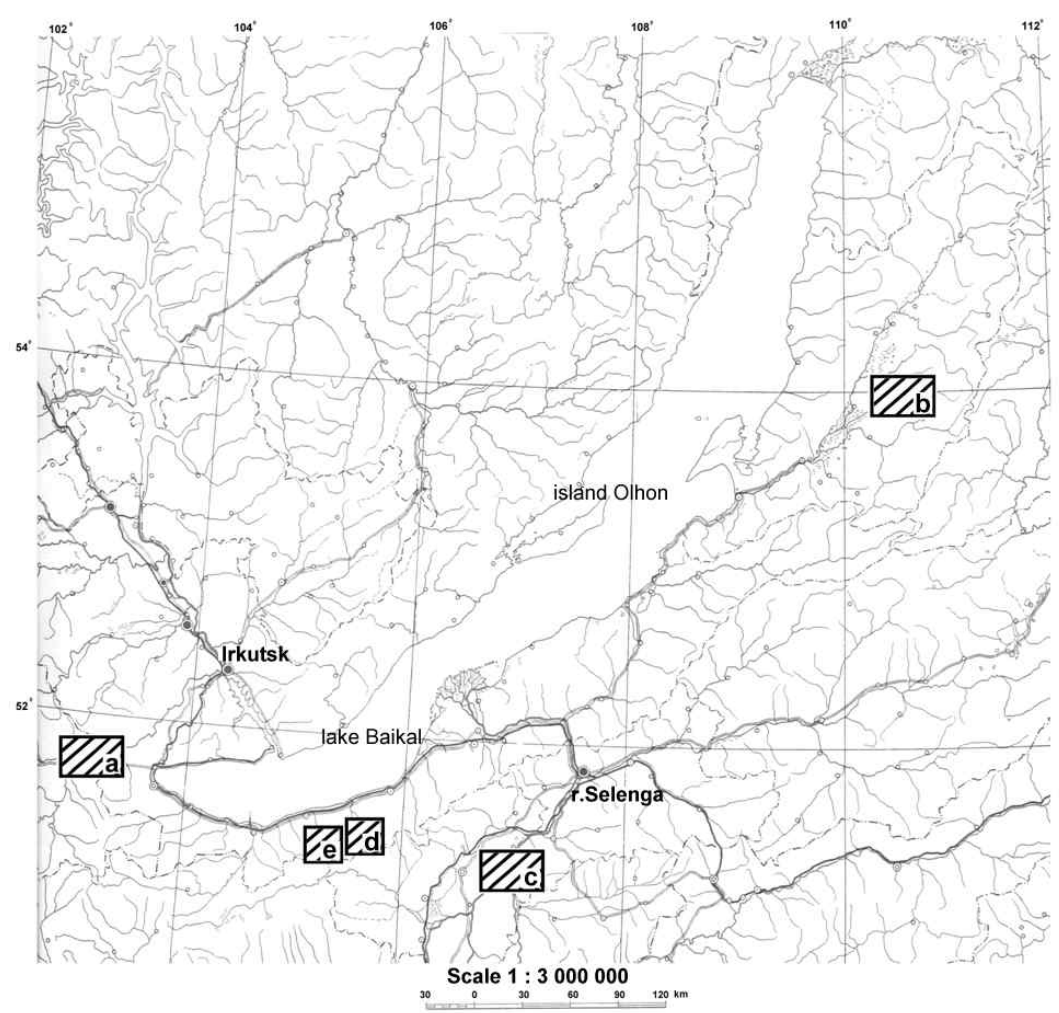

Figure 1. Areas of investigation, key territories: a - Tunka valley, b-Barguzin valley, c-Selenga river basin, e - around the Osinovka mountain, $\mathrm{d}$-around the Lysaya mountain.

soil-geobotanic profiling. Due to the application with materials of perennial monitoring and geobotanic survey, soil-geobotanic profiling favored the resolution of such tasks as establishing of the structure of communities forming at mutual development of forests and extra zonal steppes, correlation of phytocenoses with soils, as well as allowed to generate some forecasts. The profiles were designed with the aim to present all the diversity of phytocenoses and soils at the contact site of taiga and extra zonal steppe as completely as possible. The set of model communities reflects the whole spectrum of ecotopes conditions, the spatial variability, and dynamic trends of the modern vegetation in the changing climate of the region.

\section{Results}

Investigation history of the region's vegetation. The history of investigations into the vegetation of the basin of Lake Baikal was most thoroughly described (Galazy, Molozhnikov, 1982). The cited reference gives a detailed outline of all main stages of botanical studies in the region. 
The characteristic features of the floristic and phytocenotic composition of vegetation were addressed by many workers engaged with the study of the vegetative cover of the region (Popov, 1953, 1957; Peshkova, 1962, 1972, 1985, 2001; Lukicheva, 1972; Malyshev, Peshkova, 1984; Molozhnikov, 1986; Belov, 1973, 1988,1990; Kasyanova, 1993; and others.). The vegetation structure in the studied area reflects some links with the history of environmental development in the whole Baikal region. During Tertiary, on the territory of modern Pre-Baikal there were broadleaf forests, in the valleys and dry cleavages herbaceous xerophytic communities dominated. Tectonic shifts and climate changes caused disappearance of heat-loving flora. Formation of nowadays landscapes in the Central Baikal and one of modern vegetation in the coasts of Lake Baikal are related to Holocene. Climate oscillations during Holocene determined the peculiarities of spatial variability and relationship dynamics between different vegetation types in the region, in particular, variability of areas occupied by forest and steppe phytocenoses during different Holocene periods. During last decades, climate in Pre-Baikal considerably varies. Average annual winter temperatures and average annual precipitation in summer increase. Many researchers consider steppes in taiga zones as relicts which remained since vegetation formation during xerothermic periods and believe that steppe communities (steppoids) formation is the reflection of regional topologic peculiarities on the environment in the spatial structure of the vegetation cover of a concrete territory. In their opinion, such communities are not native, and during neogenetic changes they are replaced by forest ones. It is in accordance all steppe islands (out of steppe zone) have a temporary character of their existence. The modern structural and dynamic organization of vegetation on the background of climate dynamics allows us to support a viewpoint concerning the formation of communities in the area studied as a result of climatogenic succession, secular dynamics and forests evolution with formation of taiga-steppe communities of the Lake Baikal' regionl.

Current structure of the region's vegetation. The main spatial structural-typological characteristics and dynamic attributes of the Prebaikalia's vegetative cover were represented on the small-scale map of vegetation for the southern part of Siberia. According to the scheme and principles of forest-vegetation regionalization of the mountain territories of Southern Siberia (The Types..., 1980, pp. 236-243 ), the forests of the study area were assigned to the Western Prebaikalia's mountainous forest-vegetation province of larch and pine forests, of the Primorsky district of sub-taiga-forest steppe pine (Pinus sylvestris L.) and mountain-taiga larch (Larix sibirica Ledeb.) forests. These forests occupy the Primorskaya and Baikalskaya (southern part) mountain systems. Here there is a pronounced Prebaikalia's sub-boreal dry type of zonality due to increased aridity of climate that is caused by the position of the territory in the systems of the Baikal region's mountains. The basis of the region's forest vegetation is formed by pine (Pinus sylvestris L.), shrub (Rhododendron dauricum Ledeb., Duschekia fruticosa (Rupr.) Pouzar.) and grass, green-moss forests of the lower parts of slopes, and shrub (Rhododendron dauricum Ledeb.) grass pine stands of the gentle southward slopes, in combination with shrub and foxberry (Vaccinium vitis-idaea (L.) - grass forests of slopes of different exposures. Shrub (Rhododendron dauricum L.) sedge-grass-moss larch stands develop in the lower and middle parts of slopes of different exposures. Along the bottoms of valleys between mountains, ridges and slopes of southward exposure there occur steppe-like grass larch stands. All of these forests are, to some extent, in contact with steppes to form ecotone features. Pine shrub (Rhododendron 
dauricum L.), green-moss grass and grass-steppe-like forests hold a central position, which - in combination with the steppes - develop along insolated slopes and can reach the sub-golets zone. The region's steppe vegetation reflects the traits inherent in the steppes of the SouthSiberian formations that refer to the Mongolian-Chinese fratry of formations (The Vegetation..., 1972). The communities are dominates by grasses, in combination with steppe shrubs. The mountains of South Siberia are characterized by a combination of forests and steppes on slopes of eastward and southward exposures. This is typical of the mountains of Tuva, Altai, and Western Transbaikalia (Namzalov, 1994, 1996). Although the steppes of the western Prebaikalia are ascribed to the mountain-steppe zone, they have an island (azonal) character. The development of the steppes of the western Prebaikalia is associated with the character of their exposure and the stone composition of the substrate, the insufficiency of rainfall, and with strong winds that intensify transpiration in plants. Overall, all steppes of the Baikal region bear specific traits that reflect the evolution of the flora and vegetation of the region.

Current structure of the region's soils. Soils types characteristic for the steppes areas mountain-chestnut colored with salinization cases together with grey forest soils occur in the area studied. A more detailed structure of soil cover is given in the papers by V. A. Kuz'min and V.A. Snytko (1988) determining soils types which were not reported for this region before. Ts.Kh. Tsybzhitov et al. (1999) give rather unambiguous soils characteristics, stating that the base of the soil cover consists of peat-humus taiga-permafrost gleys together with gley permafrost podzols, typical brown forest soil and acidulous taiga sod. In the paper by V.A. Snytko et al. (2001), soils are characterized from viewpoint of height and exposition heterogeneities of the relief on the territory considered. Lithogenic coarse-humus, brown forest soil, podzols; primitive organogenic-rubbly (taiga-lithogenic), sod-podzol and sod forest; sod lithogenic, sod forest and sod-carbonatic; sod-forest-steppe, mountain-steppe carbonate-free, mountain chernozem-like, mountain-steppe-chestnut-colored-like soils are determined. On the slopes of different expositions and watersheds organogenic rubbly taiga (forest) soils develop often jointly with brown soils, sod-forest ones with fragments of steppe carbonatefree ones and organogenic rubbly weakly developed ones. Steppe soils are underdeveloped and not always correlate with steppe communities; they are often developed under forests. On the sites of southern exposition slopes and on flattened surfaces with dense carbonatic rocks, a friable loamy-sandy humus grey horizon with unexpressed structure is characteristic. Such soils are related to humus carbo-petrozems, a subtype of dark-humus carbo-lithozems. Contrary to the opinion existing before on a wide distribution of chernozems and chestnutcolored soils, organogenic-rubbly, chernozem-like-carbonate-free grey forest and sod forest steppificated soils dominate in the region.

\section{Spatial variability of the region's vegetation}

Many years of studies of the region's vegetation revealed some structural and dynamic features of the plant communities that reflect the present tendencies of development of the vegetative cover in connection with the changing environmental conditions: an increase in moisture content in the summer season, and the rise of yearly mean winter temperatures. Communities 
that develop in conditions of contact of the forest and steppe types of vegetation in the region may serve as good indicators of such alterations. These communities are formed by plant species with different ecological amplitudes; they respond very rapidly to and visually clearly reflect changes in ecotope conditions at the topological and regional levels of organization of the natural environment. The presence of a particular plant species (or a group of plants) in the composition of a community of the transitional type between forest and steppe suggests that there are dynamic tendencies of the vegetation in connection with changes in the ambient environment. One of such model objects that accumulate the consequences of dynamic changes of the main parameters (rainfall, temperature) if the climate in the region does include the taiga-steppe communities. Occurring throughout the western Prebaikalia, such communities are representative models for monitoring the changes in the natural environment for the last 100 years. During the last several decades the trends of development of the region's vegetation in ever changing conditions (an increase in yearly mean summer rainfall and yearly mean winter temperatures) reflect an increasingly more gradual character of the forest to steppe transition thus smoothing away the boundaries between forest and steppe and reducing the size of territories occupied by steppe communities. In some cases it is difficult to draw a demarcation line between steppe and forest. In this connection, the problem of interrelationship between forest and steppes acquires a different aspect - the dynamics of climate at a localregional level is becoming a decisive factor of development of the vegetation and, as a result, of the entire natural situation in the region. Along with a secular dynamics of the taiga where - as a consequence of the internal (coenotic) environment of phytocoenoses - there is occurring a change of forest-forming species. There are taking place spatial changes in the structure of communities, with an increasing predominance of mesophytes, or plants that demand increased moisture content of their habitats.

The work-maps, space photos, camera photos and tables for some key territories of investigation (Tunka valley, Barguzin valley, Selenga river basin and also camera photos for key territories - around Osinivka mountain, Lysaya mountain) putted as results and examples our research in Lake Baikal region (Fig. 2-12, Tables 1-3).

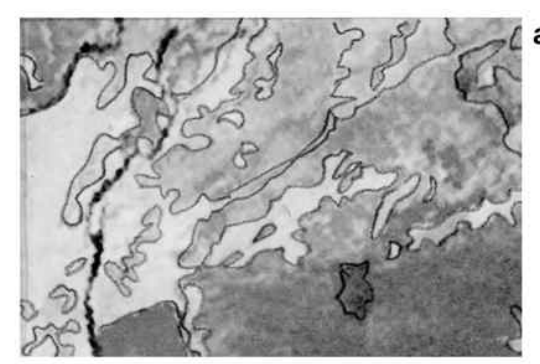

space photo 1976 year

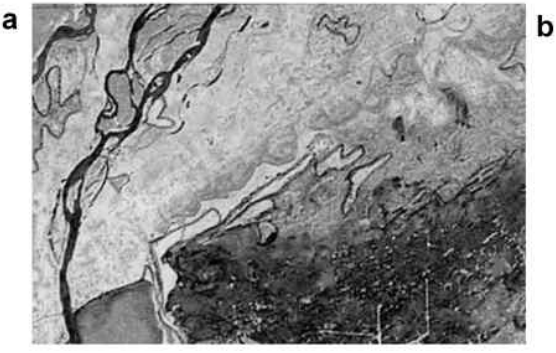

space photo 2002 year

Figure 2. Space photo for key territories - Tunka valley, a - for 1976 year, b - for 2002 year 
Pinus sylvestris L. forest in complex with steppe communities

\begin{tabular}{llll}
\hline \multicolumn{1}{c}{ Woods species } & \multicolumn{1}{c}{ Shrubs } & \multicolumn{1}{c}{ Herbs layer } & \multicolumn{1}{c}{ Mosses } \\
\hline Basic layer - Pinus sylvestris & Spiraea media Frans & Stipa krylovii Roshev., & Abietinella abietina (Turn.) \\
L., & Scmidt., just a few one & Bromopsis inermis (Leyss.) & Fleisch., Rhytidium \\
underwood - Pinus & marked. & Holub, Poa botryoides & rugosum (Hedw.) Kindb, \\
sylvestris L., underwoods & & (Trin. ex Griseb.), Artemisia & just marked under forest \\
very good developed and & frigida Willd., Galium & canopy, these species \\
growing outside of canopy & verum L., Artemisia & characteristic for \\
of forest, and between of & scoparia Waldst. Et Kit., & polydominate forest for all \\
steppe communities too. & Schizonepeta multifida (L.) & valley \\
& Briq., Sanguisorba & \\
& officinalis L. & \\
\hline
\end{tabular}

Table 1. The table of the basic composition of the plant species of the key territory - Tunka valley (a)

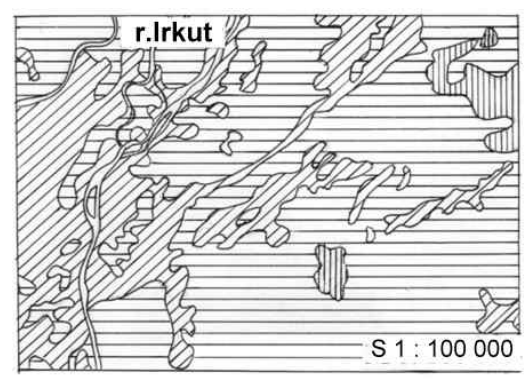

1976 year
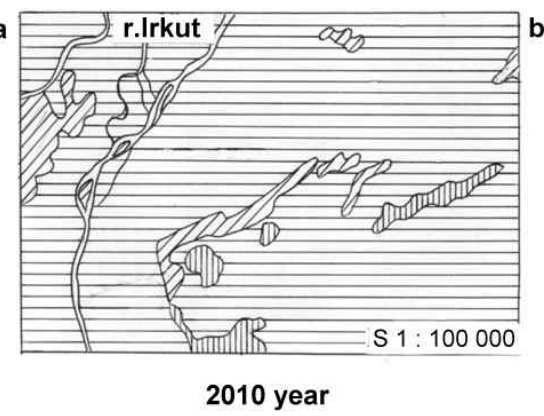

steppes

forest

- fell timber, fire places

Figure 3. Work-map of the area investigation - Tunka valley, a - just for1976 year, b-for 2010 year. 

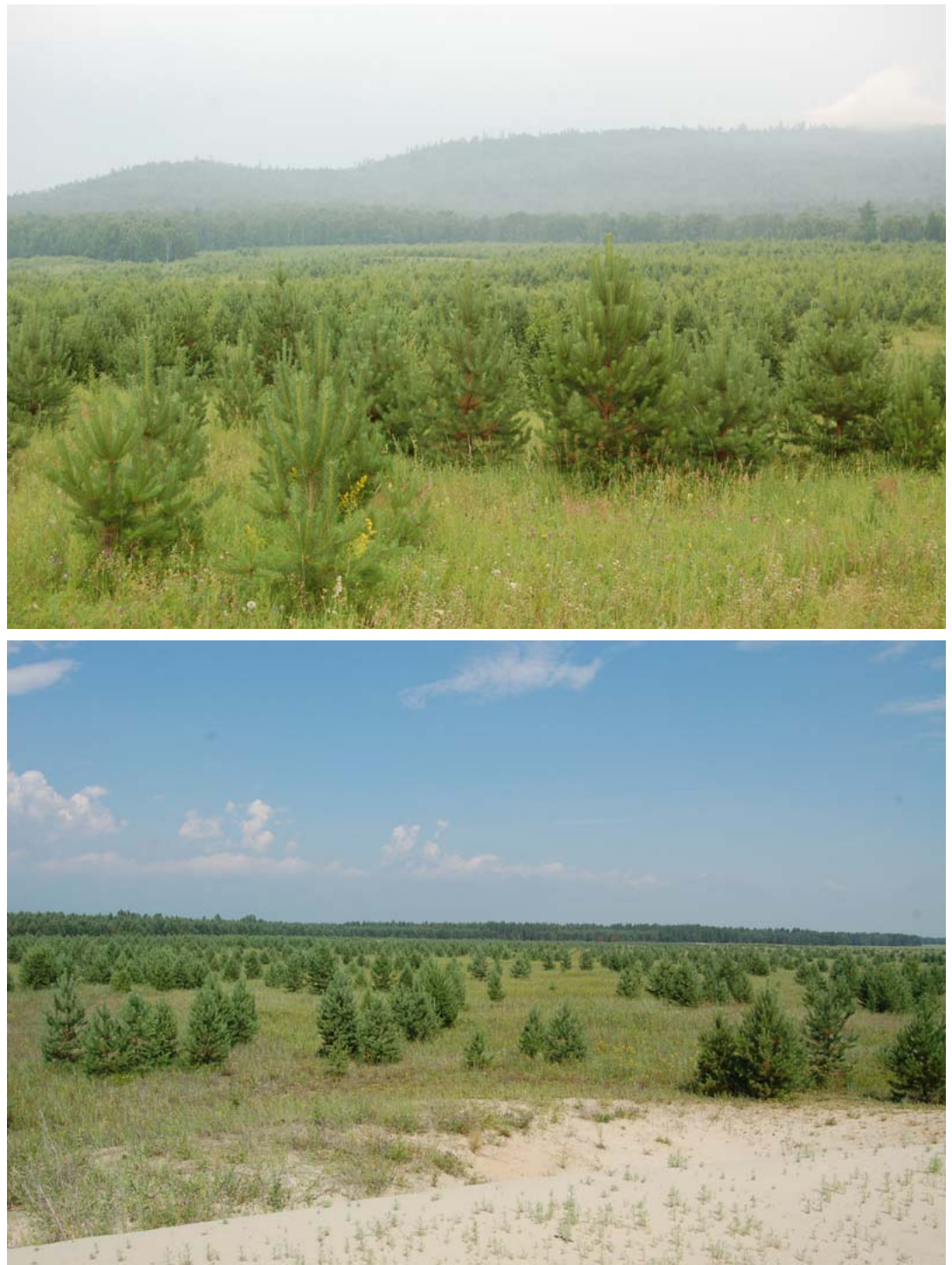

Figure 4. In the photos marked the processes of afforestation steppe land, key territories investigation - Tunka valley 
Pinus sylvestris L. forest with complex steppe communities

\begin{tabular}{|c|c|c|c|}
\hline Woods species & Shrubs & Herbs layer & Mosses \\
\hline $\begin{array}{l}\text { Basic layer - Pinus sylvestris } \\
\text { L., B underwoods - Pinus } \\
\text { sylvestris L., underwoods } \\
\text { very good developed and } \\
\text { growing outside of canopy } \\
\text { of forest, and between of } \\
\text { steppe }\end{array}$ & $\begin{array}{l}\text { Rhododendron dahuricum } \\
\text { L., Spiraea media Franz } \\
\text { Schmidt., Rosa acicularis } \\
\text { Lindley }\end{array}$ & $\begin{array}{l}\text { Diantus versicolor Fischer } \\
\text { ex Link, Veronica incana L., } \\
\text { Allium tenuissimum L., } \\
\text { Stipa krylovii Roshev, } \\
\text { Artemisia frigida L., Galium } \\
\text { verum L., Patrinia rupestris } \\
\text { (Pallas) Dufr., Eletrigia } \\
\text { repens (L.) Nevski }\end{array}$ & $\begin{array}{l}\text { Abietinella abietina (Turn.) } \\
\text { Fleisch., Rhytidium } \\
\text { rugosum (Hedw.) Kindb., } \\
\text { just marked under forest } \\
\text { canopy, these species } \\
\text { characteristic for } \\
\text { polydominate forest for all } \\
\text { valley }\end{array}$ \\
\hline
\end{tabular}

Table 2. The table of the basic composition of the plant species of the key territory - Barguzin valley (b)

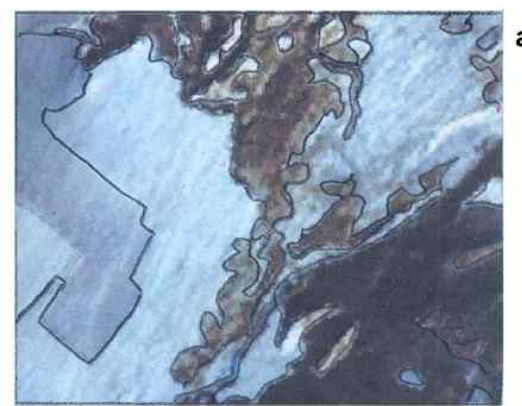

space photo 1974 year

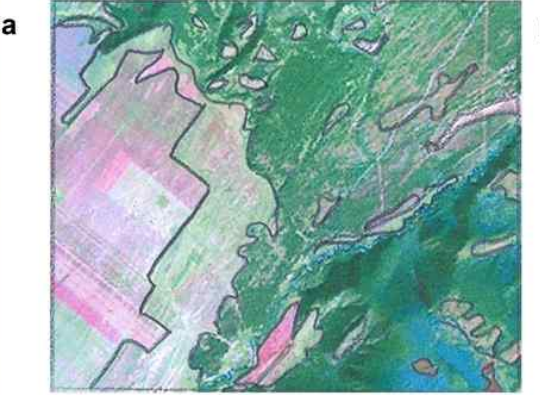

space photo 2002 year

Figure 5. Space photo for key territories - Barguzin valley, a - for 1976 year, b-for 2002 year 


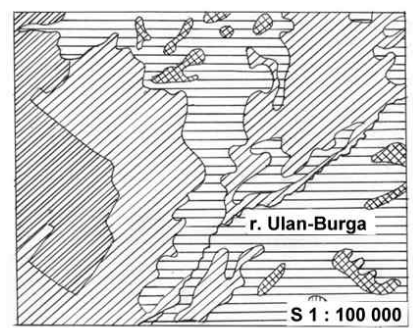

1974 year a

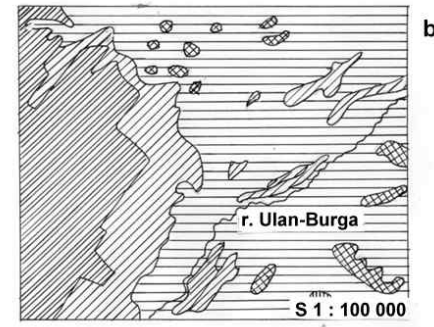

2011 year
DIIA - steppes
E- forest
DA - ploug-land
एख़ - rocks

Figure 6. Work-map of the area investigation - Barguzin valley, a - just for 1976 year, b - for 2011 year.

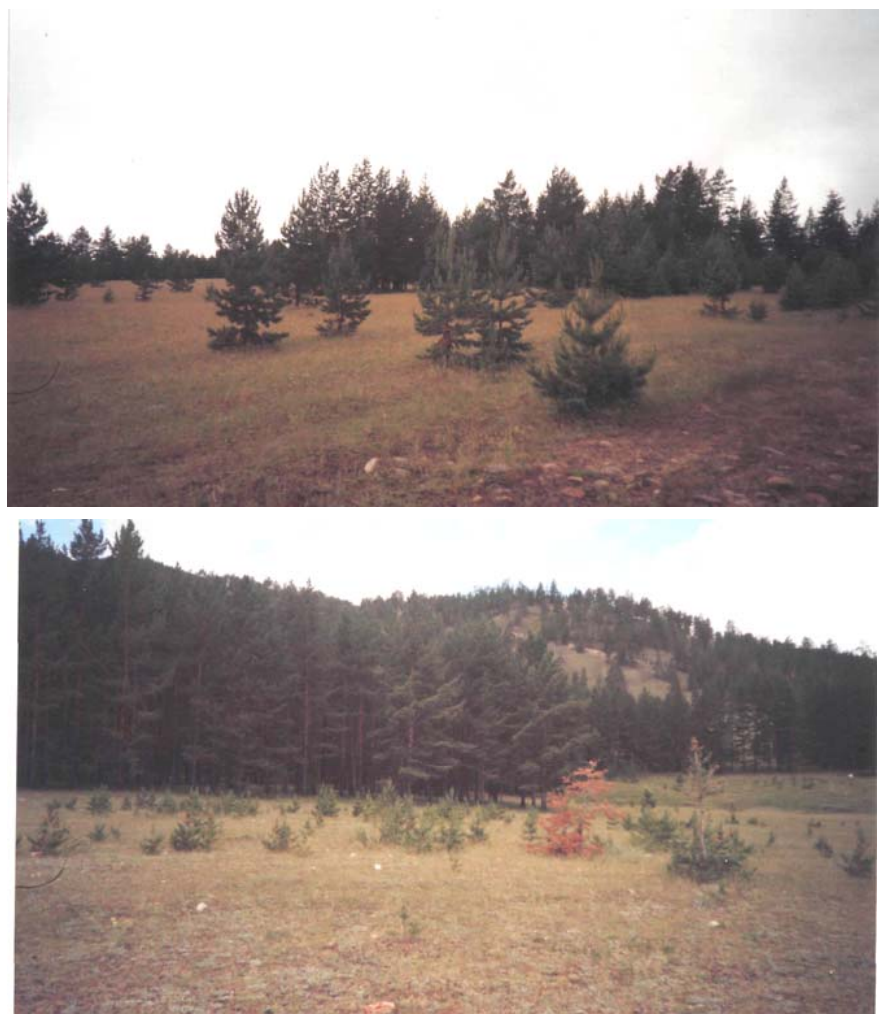

Figure 7. In the photos marked the processes of afforestation steppe land - key territories investigation - Barguzin valley 


\begin{tabular}{llll}
\hline \multicolumn{4}{c}{ Pinus sylvestris L. forest in complex with shrubs and steppe communities } \\
\hline \multicolumn{1}{c}{ Woods species } & \multicolumn{1}{c}{ Shrubs } & \multicolumn{1}{c}{ Herbs layer } & \multicolumn{1}{c}{ Mosses } \\
\hline Basic layer - Pinus sylvestris L., & Spiraea media Franz Schmidt, & Carex pediformis C.A. Meyer, & Very seldom - Pleurozium \\
underwood - Pinus sylvestris & Cotoneaster melanocarpus & Carex macroura Meinsh., & schreberii (Brid.) Mitt., \\
underwoods very good & Fischer ex Blytt, Rosa acicularis & Pulsatilla patens (L.) Miller, & Abietinella abietina (Turn.) \\
developed and growing & Lindley & Buphleurum sibiricum Vest, & Fleich, these species \\
outside of canopy of forest, & & Scorzonera radiata Fisch., Crepis & characteristic for polydominate \\
and between of steppe & sibirica L., Thalictrum foetidum & forest for all valley \\
& & L., Phlomis tuberosa L., & \\
& Potentilla bifurca L., Myosotis & \\
& imitata Serg., Vicia cracca L., & \\
& Poligala sibirica L., & \\
& Dracocephalum ruyschiana L., & \\
& Equisetum sylvaticum & \\
& &
\end{tabular}

Table 3. The table of the basic composition of the plant species of the key territory - Selenga river basin (c)

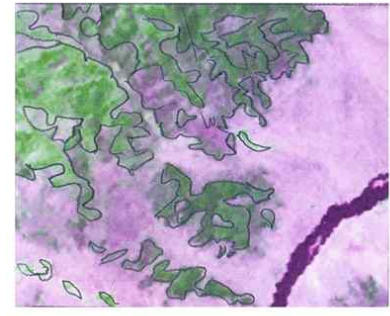

space photo 1975 year a

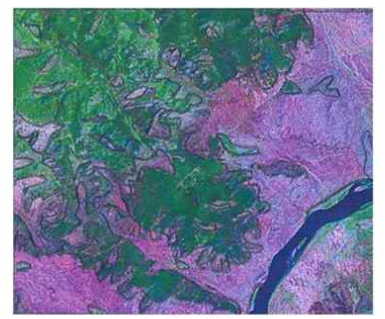

space photo 2002 year

Figure 8. Space photo for key territories - Selenga river basin, a - for 1976 year, b - for 2002 year

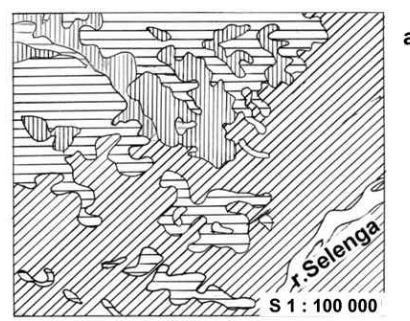

a

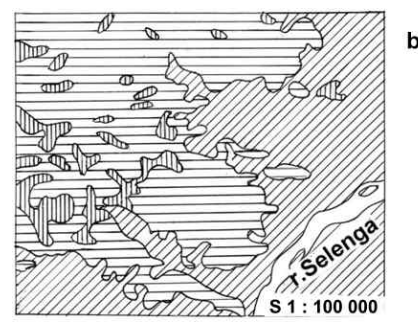

1974 year

\section{VIIJ- steppes}

forest

\section{1 year}

[IIIIII) - fire and fell timber places, rocks

Figure 9. Work-map of the area investigation - Selenga river basin, a - just for1976 year, b- for 2011 year. 


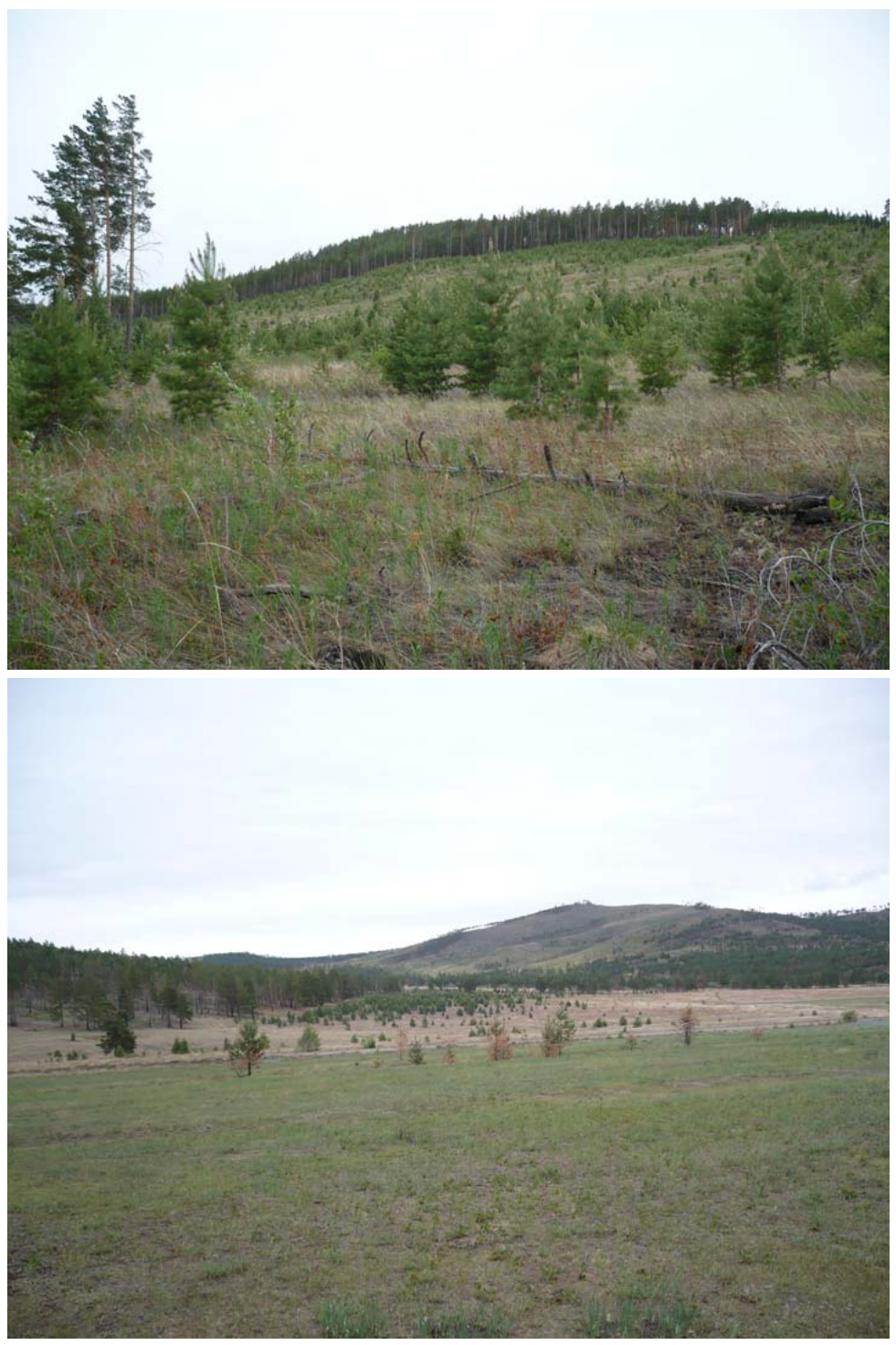

Figure 10. In the photos marked the processes of afforestation steppe land - key territories investigation - Selenga river basin 

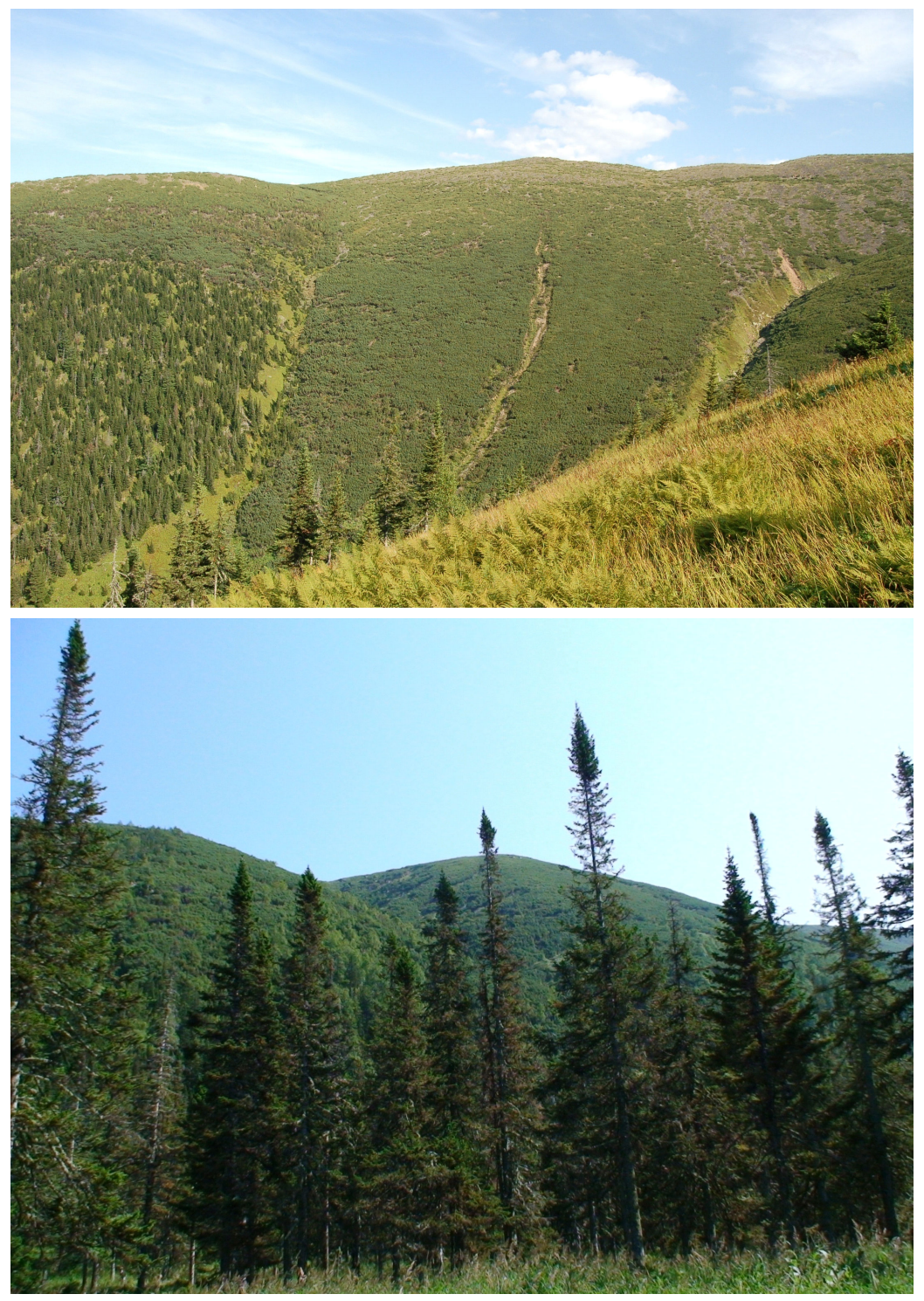

Figure 11. Key territories - around the Osinovka mountain (for 2011 year) 

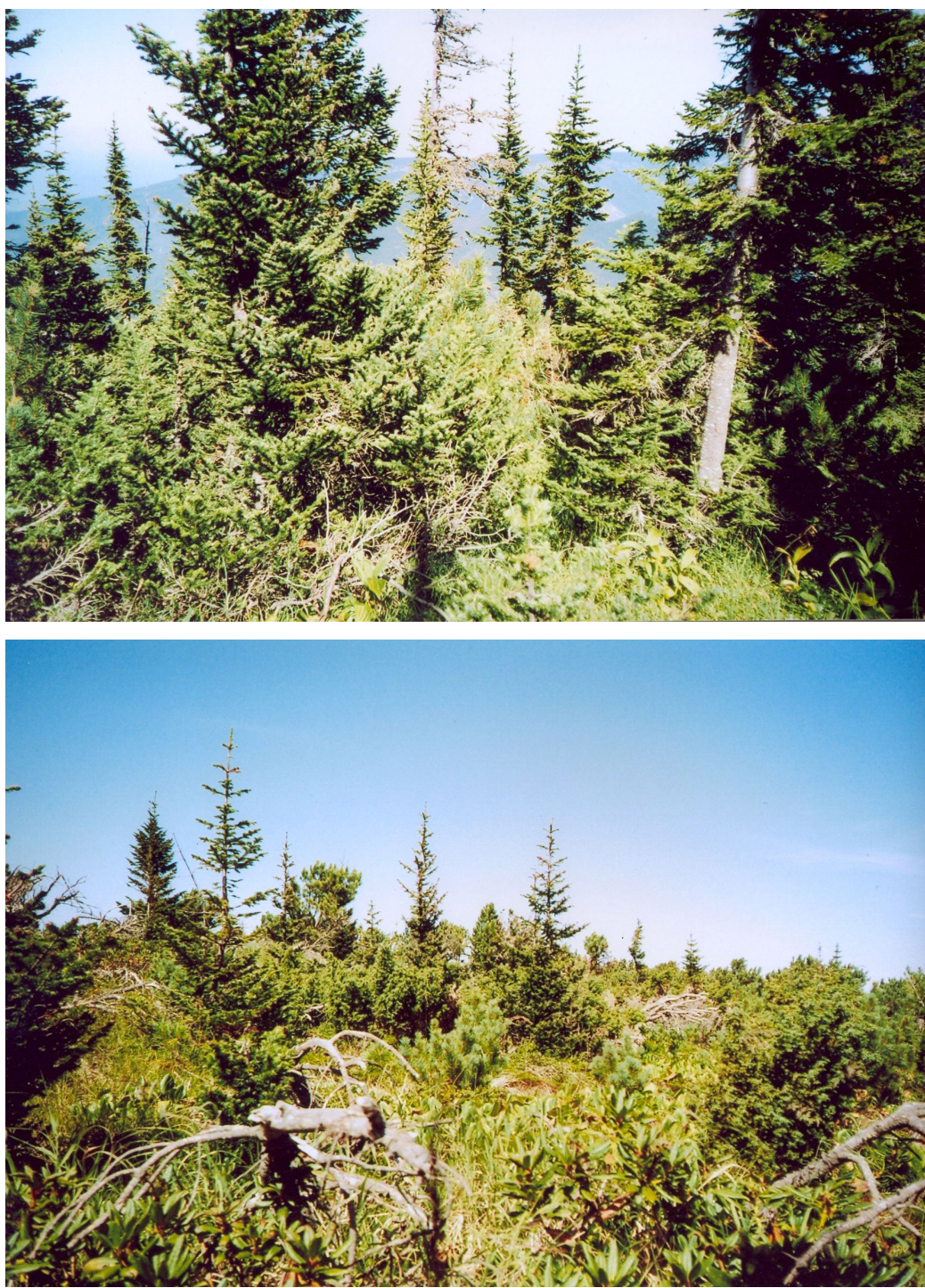

Figure 12. Key territories - around the Lysaya mountain (for 2011 year)

Tracing of soil-geobotanic profiles on the key sites reflecting the most diverse forms of forests and steppes contacts allowed to reveal the territorial diversity of the communities cenotically and typologically as well as cenoses correlation with the relief structure and with the conditions of communities habitats. The revealed character of alternation of forest and steppe communities under the conditions of extrazonality suggested that there are no clear floristic and cenotic 
links with edaphic conditions (mainly with soils) in the area studied in difference with zones or sub-zones (wooded steppe, sub-taiga). Here extra zonal effects are the most expressed in the vegetation development with manifestation of continuality (course) when there are in the communities species characteristic for dark-coniferous-light-coniferous taiga as well as xerophytic plants which make a base of cereal-motley grasses and petrophytic steppes. The occurrence of arboreal vegetation of different ages in steppe communities under the form of their gradual spatial expansion suggest mutual development and integrity of forest and steppe communities as of a united system. The formation of taiga (forest) soils here without a clear connection of steppificated soils with steppe communities shown by soil profiles combined with geobotanic ones confirms as well the opinion on the development of taiga-steppe communities specific for the area studied as on a peculiarity of the dynamics of forest type vegetation in the area studied.

\section{Discussion}

The structure of the taiga-steppe communities may be represented as a system where the coenoses consist of the tree layer dominated by Pinus sylvestris L. or Larix sibirica Ledeb. (depending on the genesis or on the recovery stage) of different age groups. The character of occurrence of Betula platyphylla Sukaczev and Populus tremula L. in tree stands is taken into account according to the genesis or recovery stage. Undergrowth is notable for an abundance of Rhododendron dauricum L. and Duschekia fruticosa (Rupr.) Pouzar. The soil cover includes the species composition of different variations, and often complexes of Vaccinium vitis-idaea L., Bergenia crassifolia (L.) Fritsch, sinuosities of Pleurosium Schreberi, Dicranum polisetum Sw., Climacium dendroides (Hedw.) Web. et Mohr., Rhytidium rugosum (Hedw.) Kindb., and for the involvement (predominance) of xerophytes, such as Festuca lenensis Drobov, Thalictrum foetidum L., Artemisa frigida Willd., Chamaerthodos altaica (Laxim.) Bunge, Iris humilis Georgi, and others. The taiga-steppe communities are characterized by the one- or two-age composition of tree species, and by the polydominance of the shrub zone and grass cover depending on the type of coenose habitat. Taiga-steppe communities are notable for dramatic restructurings of their vertical and spatial coenostructures. In addition to the development of stable young trees consisting of Pinus sylvestris L. and Larix sibirica Ledeb. in forest stands, tree ecobiomorphs are observed to actively penetrate into grass communities forming part of taigasteppe communities in the form of curtains or isolated undergrowth aged 5-15 years. In recent years, the composition of grass communities, with xerophytes forming their basis, such as Artemisa commutata Besser, Heteropappus altaicus (Willd.) Kitam., Phlomis tubirosa L., Poa attenuata Trin., and Agropyrom cristatum L., revealed saplings of tree species, pine and larch. Also, the boundary is disappearing between forest and grass phytocoenoses. The composition of the soil cover shows an ever increasing predominance of forest species with a spatial increase of sinuosities of Drepanocladus uncinatus (Hedw.) Warnst., Mnium cuspidatum Hedw., Dicranum polisetum Sw., Rhytidium rugosum (Hedw.) Kindb., and Vaccinium vitis-idaea L.A central position in grass stands corresponds to Astragalus versicolor Pallas, Galium verum L., Aster alpinum L., Trifolium lupinaster L., Potentilla tanacetifolia Willd. ex., and Campanuta glomerata L., whereas 
steppe herbage: Festuca lenensis Drobov, Koeleria cristata, Poa attenuata, and Agropyron cristatum, are somewhat less abundant and are the stage of dynamics of the community during the growth period.

It is to notice thereupon that the spatial structure of the vegetation in the area studied is particular because forest (taiga) and steppe communities form often on the same soils quite uncharacteristic for zonal steppes. Modern processes of cryolithogenic humus formation due to modern environmental conditions, to the history of formation and to vegetation cover genesis suggest that the base of soils formation is a "forest type" with some specific features due to the situation of the territory studied in the mountain system of Lake Baikal basin.

E.g., pine with motley grasses, larch (Larix sibirica Ledeb.) - pine (Pinus sylvestris L.) motley grasses-cereal forests and steppe communities with cereals domination form on organogenic rubbly-taiga (forest) soils on the slopes of different expositions. On the same soils, larch-pine sparse grass forests and steppe polydominant communities, as well as larch-pine-rhododendron ones (Rhododendron dauricum L.) with Dushekia fruticosa (Rupr.) Pouzar, red bilberries (Vaccinium vitis-idaea (L.) Avrorin) with motley grasses ones from different habitats are developed. On chernozem carbonate-free soils, there form pine-larch forests and motley grasssteppe communities, as well as larch-pine rhododendron forests with Spiraea media Fr. Schmidt on the slopes of South-Western expositions. For organogenic-rubbly steppe soils from different slopes expositions, the presence of sparse larch groups with developed underwood expanding out of a canopy among motley grass steppe communities is characteristic. In a new soil of larchpine-rhododendron forests and larch-motley grass forests developing on sod-forest and sodbrown soils a considerable role belongs to mosses characteristic for polydominant darkconiferous-light-coniferous taiga. On regosols with rocks outcrops there form everywhere motley grassed sparse pine groups with underwood and steppe communities of petrophytic series. Motley grassed steppe communities with several pine-trees aged from 2 to 60 years, are found on podzol permafrost soils jointly with organogenic-rubbly taiga (forest) soils on the slopes of different expositions.

Similar structure-dynamic peculiarities of phytocenoses and of soils in the contact zone of larch forests and extra zonal steppe cenoses are found out also at other key site. Here the boundaries of links of taiga-steppe communities with edaphic conditions are more unclear independently on types of phytocenoses habitats.

\section{Conclusions}

The presence of undergrowth and pine and larch saplings in steppe grass communities is indicative of trends toward a spatial expansion of tree ecobiomorphs in connection with an increase in yearly mean precipitation in the Prebaikalia for the last 30 years. There has been a reduction of areas occupied by steppe communities, and an active penetration of mesophytes into steppe coenoses. There is a spatial expansion of mosses characteristic for the polydominant light-coniferous - dark-coniferous taiga. The appearance of undergrowth of Pinus sibirica (Du Tour) in the composition of light-coniferous forests is a further indication that the region 
undergoes a change of climate towards an increase of moisture content and temperature. This is also supported by structural changes in the composition of the region's dark-coniferous forests where the forests of Pinus sibirica (Du Tour) develop a stable canopy of tree species demanding more moisture content - Abies sibirica (Ledeb.), and Picea obovata (Ledeb.).

The sub-golets zone of the mountains surrounding Lake Baikal reveals individual Pinus sibirica (Ledeb. ) trees, which indicates a change of the forest boundary, with a tendency towards an increase and forestation of the territories occupied by mountain-tundra plant groups. The spatial variability in the structure of the plant cover of the Prebaikalia reflects changes of the climate occurring during the last several decades in the Baikal region (Fig. 11, 12).

We can see camera photos which reflecting some processes of the spatial variability of vegetation different environment sites of the Baikal region (Fig. 4, 7, 10-12).

Soil-geobotanic studies in the region allowed to the reveal the peculiarities of phytocenoses dynamics reflecting present-day tendencies of vegetation cover development due to changing environmental conditions - humidity increase in summer and increase of average annual temperatures in winter. Good indicators of such changes are taiga-steppe communities of the Lake Baikal region manifesting the peculiarities of relationship in spatial variability of forests and of steppes communities. These communities formed by plants species with different ecological amplitudes respond very rapidly and reflect visually changes in ecotops conditions at topological and regional levels of environment organization. The presence of one or other plant species (or species group) in a concrete community allows to suppose dynamic tendencies of vegetation due to environmental changes. Taiga-steppe communities on all the of Lake Baikal region can be representative models reflecting peculiarities of structural-dynamic organization of the vegetation on the background of climate dynamics in the region during last decades.

The present-day tendencies of vegetation development reflect a transitional character of the steppes in the central part of the coasts with tendencies of disappearing of a boundary between forest and steppe communities. Thereupon the problem of finding out the character of relationship between forest and steppe communities is brought to the task to determine a way and dynamics of climatic factors at local-regional level under the conditions of changing of the environment as a whole. Along with secular dynamics of taiga, when due to changes in the internal (edapho-cenotic) environment of phytocenoses, forest-forming species change, and there are other changes in the spatial structure of the communities. On upper soil cover in the forests, spatial expansion of mosses synusia characteristic for a polydominant dark-coniferouslight-coniferous taiga occurs. Appearing of Pinus sibirica Du Tour underwood among lightconiferous forests can also suggest that in this region, along with recoverable vegetation dynamics, there occur change sin communities structure responding to changing climatic situation in this region. It is to notice thereupon that among the forests of Primorsky and Baikal'sky Ridges a stable canopy is forming of tree species more exigent to humidity - Abies sibirica Ledeb., Picea obovata Ledeb. Among mountain tundras there are some trees Pinus sibirica aged from 2 to 25 years. 
Due to the peculiarities revealed among spatial-structural links of vegetation and soil cover in the area studied using combined soil-geobotanic profiles on the key sites, it is possible to make a conclusion that it is not so rightful to characterize the vegetation as forest and steppe types. In this very case, forest and steppe communities at environments contact site (taiga-steppe) are genetically united. Under the contrast conditions of the environment of the area studied, vegetation formation is due to climatogenic paragenesis as indicated by the results of our studies. The vegetative cover in this case serves as an indicator of the changing natural situation in the region. This would be reflected not only in the formation of the environmental conditions for the period of relative warming, as was the case at different stages of the Holocene, but also in the policy of economic development of the region as a whole.

\section{Acknowledgements}

This scientific work has been made by financial support of the Integration Parthenship Project of Russian Academy of Sciences (№ 69) and Russian Fond of Basic Research 12-04-09- 980013p_siberia_a

\section{Author details}

A. P. Sizykh* and V. I. Voronin

*Address all correspondence to: alexander_sizykh@yahoo.com

Laboratory of Ecosystem Bioindication, Siberian Institute of Plant Physiology and Biochemistry, Siberian Branch of Russian Academy of Sciences, Irkutsk, Russia

\section{References}

[1] Alexander Sizykh, Victor Voronin, Michail Azovsky, Svetlana Sizykh. Paragenese of the vegetation in ecosystems contact zones (in Lake Baikal basin) // Natural Sciences. (2012). , 4(5), 271-275.

[2] Belov, A. V. (1973). The Map of the Vegetation of the South of East Siberia. Principles and Methods of Compilation. Geobotanical Mapping, Leningrad: , 16-30.

[3] Belov, A. V. (1988). A cartographic study of the vegetation of the Pribaikalsky National park. Recreation and Protected Areas. Proceedings of the. 5th Meeting on Applied Geography, Irkutsk, , 66-78.

[4] Belov, A. V. (1990). The Vegetation. Nature Management and Environmental Protection in the Baikal's Basin, Novosibirsk:, 147-154. 
[5] Belova, V. A. (1975). The History of Development of Vegetative Depressions of the Baikal Rift Zone, Moscow.

[6] Belova, V. A. (1985). The Vegetation and Climate of the late Cainozoic in the South of East Siberia, Novosibirsk.

[7] Bezrukova, E. V. (1996). The Vegetation and Climate of the Prebaikalia in the Late Glaciation Era and Holocene. Author's Abstract of the Dissertation (Cand.Sc. Geogr.), Irkutsk.

[8] Bezrukova, E. V. (2002). The Vegetation and Climate of the South of East Siberia in the Late Neopleistocene and Holocene. Author's Abstract of the Dissertation (Cand.Sc. Geogr.), Irkutsk.

[9] Galazy, G. I, \& Moloznikov, V. N. (1982). The History of Botanical Studies at Lake Baikal, Novosibirsk.

[10] Gustokashina, N. N. (2003). Long-Term Changes of the Main Climate Elements on the Territory of the Prebaikalia, Irkutsk.

[11] Grichuk, M. P. (1955). Toward the History of the vegetation in the Angara River basin. Dokl. AN SSSR. Nov. Ser. , 2, 335-338.

[12] Dylis, N. V, Reshikov, L. I, \& Malyshev, L. I. (1965). The vegetation. In: The Prebaikalia and Transbaikalia, Moscow, , 225-281.

[13] Kapralov, D. S, Shiytov, S. G, Moiseev, P. A, \& Fomin, V. V. Changes in the Composition, Structure and Altitudinal Distribution of Low Forests at the Upper Limit of Their Growth in the Northern Ural Mountains // Russian Journal of Ecology, (2006). , 37, 367-372.

[14] Kasyanova, L. N. (1980). Plant Ecology of the Steppes in the Olkhon Region, Novosibirsk

[15] Kuz'min V ASnytko V.A. (1988). Geochemical differences of soils in contrast landscapes within Pre-Baikal National Park. Soils geography and geochemistry of Siberian landscapes: , 41-55.

[16] Lukicheva, A. N. (1972). The regularities of vertical zonality of vegetation associated with terrain and rock characteristics (a case study of the Baikal ridge). Geobotanical Studies and Dynamics of Shores and Slopes at Baikal, Leningrad: , 3-70.

[17] Malyshev, L. I, \& Peshkova, G. A. (1984). The Peculiarities and Genesis of the Flora of Siberia, Prebaikalia and Transbaikalia, Novosibirsk.

[18] Moloznikov, V. N. (1986). Plant Communities of the Prebaikalia, Novosibirsk.

[19] The Types of Forests in the South of East Siberia(1980). Novosibirsk: , 236-243.

[20] Namzalov, B. B. (1994). The Steppes of Southern Siberia, Novosibirsk-Ulan-Ude. 
[21] Namzalov, B. B. (1996). The mountain forest-steppe of Southern Siberia landscape phenomenon of Central Asia. The Flora and Vegetation of Siberia and the Far East. Lectures in the memory of L.M.Cherepnin. Book of Abstracts of the nd All-Russia Conference, Krasnoyarsk: 215-217., 2.

[22] Peshkova, G. A. (1962). Forest-steppe relationship in the Angara region. Trans. EastSib. Biol. Inst. , 1, 90-99.

[23] Peshkova, G. A. (1972). The Steppe Flora of Baikalian Siberia, Moscow.

[24] Peshkova, G. A. (1985). The Vegetation of Siberia, Prebaikalia and Transbaikalia, Novosibirsk.

[25] Peshkova, G. A. (2001). Florogenetic Analysis of the Steppe Flora of the Mountains in Southern Siberia, Novosibirsk.

[26] Popov, M. G. (1953). On the relationship of forest (taiga) and steppe in Middle Siberia. Bull. of Moscow Soc. of Naturalists, Biol. Dept. 58, 5: 81-85.

[27] Popov, M. G. (1957). The steppe and rock floras of the Baikal's western shore area. Trans. Baik. Limnol. st. , 15, 408-426.

[28] Savina, L. N. (1986). Taiga Forests of Northern Asia in the Holocen, Novosibirsk.

[29] Sizykh, A. P. Protection of the taiga-steppe ecosystems of the western shore of Lake Baikal // Journal of Design \& Nature and Ecodynamics, UK, (2009). , 4, 66-71.

[30] Snytko, V A. Dan'ko L V, Kuz'min S B, Sizykh A Diversity of geosystems of taiga and steppe contact on the Western coast of Lake Baikal. Geography and Natural Resources: 61-68., 2001.

[31] ShiytovS. GTerent'ev M.M., Fomin V.V. Spatiotemporal Dynamics of Forest-Tundra Communities in the Polar Urals // Russian Journal of Ecology, (2005). , 36, 69-75.

[32] The Types of Forests in the South of East Siberia(1980). Novosibirsk: , 236-243.

[33] The Vegetation (South of East Siberia)(1972). Map 1: 1500000 (ed. by A.V.Belov), GUGK.

[34] Thomas, T. Veblen and Diane C. Lorenz. (1988). Recent vegetation changes along the forest/steppe ecotone of Northern Patagonia. Annals of the Association of American Geographers. , 78, 93-111.

[35] Tsybzhitov Ts KhTsybikdorzhiev Ts Ts, Tsybzhitov A I. (1999). Soils of Lake Baikal basin: 128 .

[36] VoroninV. I Sizykh A. P Oskolkov V. A Voronin, Sheifer E.V. Structural-dynamics organization of the plant communities of the basic ecotones of the Lake Baikal // Environments- 2010, Russia, Tomsk, (2010). , 45-46. 